\title{
Nilai-Nilai Pendidikan Hindu Dalam Upacara Perkawinan Hindu Kaharingan Dayak Ngaju
}

\author{
Pranata \\ Institut Agama Hindu Negeri Tampung Penyang (IAHN-TP) Palangka Raya \\ adityaken@yahoo.com
}

\begin{abstract}
Riwayat Jurnal
Artikel diterima: 3 September 2018

Artikel direvisi: 16 November 2018

Artikel disetujui: 20 November 2018

Kata Kunci:

Upacara,

Perkawinan,

Hindu Kaharingan.

Abstrak

Pendidikan adalah salah satu upaya yang berguna untuk mewariskan nilai, sebagai penolong dan penuntun dalam menjalani kehidupan bermasyarakat serta sekaligus untuk memperbaiki nasib dan peradaban umat manusia dalam menghadapi tantangan zaman globalisasi yang akan membawa perubahan terhadap kehidupan masyarakat. Firman Ranying Hatalla merupakan pedoman bagi pemeluk agama Hindu Kaharingan apabila melaksanakan upacara perkawinan, maka haruslah berdasarkan pada Pelek Rujin Pangawin Nyai Endas Bulau Lisan Tingang dengan Raja Garing Hatungku, dengan melaksanakan Pelek Rujin Pangawin tersebut maka akan terciptalah kehidupan rumah tangga yang harmonis, bahagia dan sejahtera baik lahir maupun bathin. Khusus untuk upacara perkawinan umat Hindu Kaharingan yang merupakan suatu firman dari Ranying Hatalla Langit kepada umat Hindu Kaharingan untuk selalu dilaksanakan, maka kewajiban kita untuk menjaga dan melestarikannya sehingga nilai-nilai pendidikan agama Hindu akan selalu melekat dan dipahami oleh seluruh generasi Hindu. Nilai-nilai pendidikan dalam upacara Perkawinan Umat Hindu Kaharingan di Kota Palangka Raya maka dapat digali berupa Nilai Kontruktif yaitu Nilai Religi dan Nilai Kebenaran, Nilai Positif yaitu Nilai-Nilai Positif dan Nilai-Nilai Kebaikan, Nilai Kognitif yaitu Nilai Pengetahuan yang terkandung dalam Upacara Perkawinan Umat Hindu Kaharingan dan bagaimana proses Transformasi nilai tersebut, Nilai Expresif yaitu nilai keindahan dan rasa bakti dalam upacara Perkawinan umat Hindu Kaharingan Dayak Ngaju.

\section{Keyword:}

Ceremony,

Marriage,

\section{Abstract}

Education is one of the efforts that are useful for passing the value, as a helper and a guide to live a social life as well as to improve the mankind and civilization in the face of the challenges of the globalization era that will bring change to people's lives.
\end{abstract}




\begin{tabular}{|l|l|}
\hline Hindu Kaharingan. & The word Ranying Hatalla the guidelines for religious Hindus \\
Kaharingan if the marriage ceremony. It should be based on Pelek \\
Rujin Pangawin Nyai Endas Bulau Lisan Tingang dan Raja \\
Garing Hatungku. The implementation of pelek rujin Pangawin \\
that will be creating a harmonious home life happy and \\
prosperous both physically and spiritual. Especially for people \\
marriage ceremony Hindu Kaharingan which is a the word of \\
Ranying Hatalla Langit the Hindus Kaharingan for always done, \\
then our obligation to maintain and preserve it so that the values \\
of Hinduism education will always be attached to and understood \\
byall generations of Hindu. Whereas for multiplying the values in \\
the Hindu Kaharingan marriage ceremony dayak Ngaju it can be \\
extracted in the form of constructive value and the value of the \\
Religious Value Truth, Positive value of the Positive Values and \\
Values Goodness, Cognitive Value is value embodied knowledge \\
in Hindu Kaharingan Marriage Ceremony and how that value \\
transformation process, Expresif value ie the value of beauty and \\
devotion in Hindu Kaharingan marriage ceremony Dayak Ngaju. \\
\hline
\end{tabular}

\section{Pendahuluan}

Pendidikan adalah salah satu upaya yang berguna untuk mewariskan nilai, sebagai penolong dan penuntun dalam menjalani kehidupan bermasyarakat serta sekaligus untuk memperbaiki nasib dan peradaban umat manusia dalam menghadapi tantangan zaman globalisasi yang akan membawa perubahan terhadap kehidupan masyarakat. Menghadapi zaman yang menglobal dewasa ini tentunya akan sangat berpengaruh kepada nilai-nilai yang sudah dipegang teguh oleh masyarakat Indonesia yang terkenal sebagai bangsa yang memegang teguh adat dan budaya. Di dalam Pelestarian nilai-nilai tersebut, salah satu jalur yang harus memegang peran yang sangat penting adalah jalur pendidikan.

Banyak sekali upacara-upacara ritual yang dilaksanakan oleh penganut agama Hindu Kaharingan dan mempunyai ciri khas tersendiri, (tradisi melaksanakan upacara ini sangat identik dengan agama Hindu Kaharingan). Begitu juga dengan upacara perkawinan, masingmasing suku seperti suku Dayak Ngaju, Dayak Maanyan, Ot Danum, Ot Siang, Lawangan, Katingan dan sebagainya. Tentunya memiliki ciri khas tersendiri tetapi secara esensial adalah mengacu kepada firman Ranying Hatalla Langit (sebutan Tuhan menurut Agama Hindu Kaharingan) yang tertuang dalam Kitab Suci Panaturan.

Berdasarkan firman Ranying Hatalla Langit dalam Kitab Suci Panaturan pasal 54 ayat 4 (Tim, 2001: 45) berbunyi:

"Melalui Bawi Ayah turun mengajarkan keturunan Raja Bunu di Pantai Danum Kalunen, supaya di dalam kehidupannya, mereka melakukan Pelek Rujin Pangawin 
itu sungguh-sungguh agar hidup mereka mudah rejeki, panjang umur, kaya raya, bahagia dan sejahtera".

Firman Ranying Hatalla inilah merupakan pedoman bagi pemeluk agama Hindu Kaharingan apabila melaksanakan upacara perkawinan, maka haruslah berdasarkan pada Pelek Rujin Pangawin Nyai Endas Bulau Lisan Tingang dengan Raja Garing Hatungku, dengan melaksanakan Pelek Rujin Pangawin tersebut maka akan terciptalah kehidupan rumah tangga yang harmonis bahagia dan sejahtera baik lahir maupun bathin. Hal tersebut dikemukakan Hadikusuma (1977: 70) menyatakan sebagai berikut.

"Perkawinan tidak semata-mata berarti suatu ikatan antara seorang pria dengan seorang wanita sebagai suami istri untuk maksud mendapatkan keturunan dan membangun serta membina kehidupan keluarga rumah tangga tetapi juga berarti suatu hubungan hukum yang menyangkut para anggota kerabat dari pihak istri dan suami. Terjadinya perkawinan berarti berlakunya ikatan kekerabatan untuk saling membantu dan menunjang hubungan kekerabatan yang rukun dan damai““.

Dari beberapa pandangan di atas, maka perkawinan yang ideal yaitu dapat memenuhi semua norma yang ada di masyarakat. Kondisi ini mengalami tantangan, karena tata cara perkawinan pada masa sekarang cenderung mengarah kepada hal yang cepat dan praktis dengan melupakan nilai-nilai sakral yang terdapat dalam proses Upacara Ritual perkawinan. Meskipun Suku Dayak tidak semua menganut agama Hindu Kaharingan, tetapi nafas budaya dan tradisi Kaharingan sangat kuat pengaruhnya dalam setiap kehidupan suku Dayak khususnya di Kalimantan Tengah.

Di dalam Kitab Manawadharmasastra Buku III Pasal 4 mengatakan:

"Gurunanumatah snatwa

swawrtto yathawidhi,

Udwaheta dwijo bharyam

Sawarnam laksananwitam “

Artinya:

"Setelah mandi, dengan seijin gurunya dan melakukan sesuai dengan peraturan upacara samawartana, seorang Dwijati akan mengawini seorang perempuan dari warna yang sama yang memiliki tanda-tanda baik pada badannya".

(Pudja.1978, 131).

Makna dari pernyataan di atas, maka apa yang menjadi tujuan dari perkawinan yaitu ingin menciptakan suatu keluarga yang bahagia dan sejahtera akan tercapai apabila pasangan suami istri tersebut berasal dari keluarga yang baik dan yakin kepada Tuhan Yang Maha Esa.

Setiap pasangan yang ingin membentuk rumah tangga harus sadar tentang tanggung jawab sebagai suami istri dan yang paling penting adalah bagaimana sepasang suami istri 
tersebut mampu mengedepankan ajaran agama terutama bila ia ingin melangsungkan perkawinan. Hal ini seperti yang tertuang dalam Kitab Suci Panaturan Pasal 19 ayat 3 (Tim, 2001) yaitu:

"Ewen due puna palus lunuk hakaja panting baringen hatamuei bumbung, awi ewen sintung due dapit jeha ije manak manarantang hatamunan aku huang pantai danum kalunen ije puna ingahandak awi-Ku tuntang talatah panggawi manjadi suntu akan pantai danum kalunen ".

Dari pasal 19 Kitab suci Panaturan ini sangatlah jelas bagi umat Hindu Kaharingan pastilah nantinya untuk melangsungkan kehidupan dan penerusan keturunan harus melalui proses perkawinan.

Begitu juga seperti yang tertuang dalam Kitab Suci Panaturan Pasal 28 ayat 40 yaitu:

"Limbah jadi malalus kakare gawi akan Raja Bunu ewen due Kameluh Tanteluh Petak maatuh kabaluma belum mangun batang panjang huma hai parataran lumbah".

Dengan demikian tujuan perkawinan menurut agama Hindu Kaharingan yaitu menginginkan dalam menjalankan kehidupan, mereka mampu untuk menjalani kehidupannya guna membangun rumah tangganya dalam sebuah rumah yang besar menjadi rumah tangga yang bahagia dan sejahtera. Kebahagian dalam keluarga tidak saja menumpuknya harta benda, tidak saja terpenuhinya sex, tetapi terpenuhinya kebutuhan jasmani dan rohani yang wajar. Anak/keturunan merupakan kelanjutan dari siklus kehidupan keluarga, oleh sebab itu diharapkan dalam sebuah keluarga dapat melahirkan anak/keturunan. Khusus untuk upacara perkawinan umat Hindu Kaharingan yang merupakan suatu firman dari Ranying Hatalla Langit kepada umat Hindu Kaharingan untuk selalu dilaksanakan, maka kewajiban kita untuk menjaga dan melestarikannya sehingga nilai-nilai pendidikan agama Hindu akan selalu melekat dan dipahami oleh seluruh generasi Hindu.

\section{Pembahasan}

\section{Proses Awal Sebelum Upacara Perkawinan}

Ajaran Agama Hindu Kaharingan, upacara perkawinan adalah suci yang harus dilaksanakan oleh setiap pasangan yang akan hidup berumah tangga. Setiap pasangan yang ingin membentuk rumah tangga harus sadar tentang tanggung jawab sebagai suami istri dan yang paling penting adalah bagaimana sepasang suami istri tersebut mampu mengedepankan ajaran agama terutama bila ia ingin melangsungkan perkawinan. Hal ini seperti yang tertuang dalam Kitab Suci Panaturan Pasal 19 ayat 3 yaitu :

"Ewen due puna palus lunuk hakaja panting baringen hatamuei bumbung, awi ewen sintung due dapit jeha ije manak manarantang hatamunan aku huang pantai danum 
kalunen ije puna ingahandak awi-Ku tuntang talatah panggawi manjadi suntu akan pantai danum kalunen".

Pasal 19 Kitab suci Panaturan ini sangatlah jelas bagi umat Hindu Kaharingan pastilah nantinya untuk melangsungkan kehidupan dan penerusan keturunan harus melalui proses perkawinan. Firman Ranying Hatalla Langit inilah merupakan suatu pedoman bagi anak cucu Raja Bunu (manusia) di Pantai Danum Kalunen (Dunia) apabila di dalam menjalankan upacara perkawinan, maka wajiblah berdasarkan pada Pelek Rujin Pangawin. Dengan dilaksanakan Pelek Rujin Pangawin inilah nantinya berkat doa dan anugrah Ranying Hatalla Langit maka akan tercipta rumah tangga yang harmonis, bahagia dan sejahtera baik lahir maupun batin suci.

Upacara Perkawinan menurut ajaran agama Hindu Kaharingan Dayak Ngaju terdapat berbagai rangkaian upacara yang harus dilaksanakan oleh kedua mempelai yaitu:

\section{Hakumbang Auh}

Pelaksanaan upacara hakumbang auh yaitu dilakukan dari pihak laki-laki yang menginginkan seorang perempuan untuk dijadikan istrinya yaitu berupa penyerahan sejumlah uang sebagai tanda bahwa dari pihak laki-laki menginginkan seorang perempuan kepada pihak perempuan. Adapun jumlah uang yang diberikan tidak ditentukan jumlahnya melainkan tergantung kemampuan dari pihak laki-laki.

Uang yang diserahkan tersebut dan diterima oleh pihak perempuan akan digunakan oleh pihak keluarga perempuan untuk mengumpulkan seluruh keluarganya dan menceritakan maksud dari uang tersebut bahwa ada pihak laki-laki yang menginginkan anak perempuannya untuk dijadikan istri. Apakah uang tersebut dapat diterima atau ditolak. Apabila hasil kesepakatan keluarga pihak perempuan menolak uang tersebut, perwakilan pihak keluarga perempuan mengembalikan uang tersebut. Dan apabila dapat menerima uang tersebut, pihak keluarga perempuan mengirim pesan atau mengunjungi pihak keluarga laki-laki bahwa uang tersebut dapat diterima dan mengharapkan kehadiran pihak laki-laki untuk membicarakan kelanjutan sekaligus untuk membicarakan jalan hadat yang digunakan. Setelah seluruh keluarga mengetahui semua, maka mereka lalu merencanakan untuk berangkat misek.

\section{Maja Misek (Mamanggul)}

Maja misek/mamanggul bertujuan untuk bersama-sama membicarakan guna merencanakan kelanjutan dari rencana perkawinan serta merundingkan tentang jalan hadat pada saat upacara perkawinan nantinya. Adapun sarana yang akan digunakan untuk maja misek yang dipersiapkan oleh pihak laki-laki yaitu satu buah garantung (gong), satu buah lilis 
lamiang, kain pakaian selengkapnya. Setelah semua siap maka mereka berangkat menuju ke rumah pihak perempuan.

Setelah sampai di tempat pihak perempuan, mereka bersama-sama merundingkan rencana perkawinan tersebut. Di hadapan seluruh keluarga, pihak keluarga dari pihak perempuan menguraikan tentang seluruh jalan hadat yang akan digunakan, serta menentukan lamanya waktu perkawinan (jalan hadat yang digunakan biasanya adalah jalan adat dari perkawinan orang tua pihak perempuan). Setelah ada kesepakatan maka kedua belah pihak sepakat untuk menandatangani kontrak janji peminangan (hisek). Kedua orang tua pihak lakilaki setelah sampai di rumahnya mengikat lilis lamiang kepada anak laki-lakinya dan mambuwur behas hambaruan serta menceritakan lamanya janji perkawinan dan jalan hadat yang harus dipenuhi oleh pihak laki-laki.

\section{Mananggar Janji}

Mananggar janji adalah penegasan waktu dan tempat pelaksanaan perkawinan. Dimana di dalam acara mananggar janji ini pihak orang tua dari pihak perempuan datang mengunjungi ke rumah pihak laki-laki guna mananggar janji serta untuk menagih rapin tuak. Setelah kedua belah pihak sepakat tentang tanggal pelaksanaan perkawinan tersebut, maka orang tua pihak laki-laki akan menyerahkan segala biaya kepada orang tua pihak perempuan untuk biaya panginan jandau (biaya makanan untuk resepsi) serta biaya untuk membelikan tempat tidur pengantin sesuai dengan jumlah yang telah disepakati pada saat maja hisek.

\section{Pelaksanaan Upacara Perkawinan}

Proses pelaksanaan upacara perkawinan umat Hindu Kaharingan Dayak Ngaju dengan beberapa rangkaian acara yaitu:

\section{Penganten Mandai}

Proses pelaksanaan upacara penganten mandai, satu hari sebelum waktu pelaksanaan upacara perkawinan dilaksanakan, orang tua pihak laki-laki menyembelih/memotong satu ekor ayam jantan yang diambil darahnya untuk manyaki rambat (rambat adalah sejenis tas yang terbuat dari rotan) anaknya yang akan segera berangkat melangsungkan perkawinannya, juga disiapkan satu buah sipet (tombak sumpit), uei ije kadereh (rotan satu buah). Satu buah rotan tersebut diukur sepanjang satu depa (sepanjang dua buah tangan orang dewasa), satu hasa, satu kilan dan tiga jari, selanjutnya rotan tersebut dibuatkan ukiran patung pada ujungnya pangkalnya. Setelah diadakan upacara manyaki rambat tersebut maka sejak hari tersebut pengantin laki-laki disebut dengan Penganten, dan pada saat itu akan diikatkan satu 
buah lilies lamiang. Sejak hari itu pengantin laki-laki tidak boleh keluar rumah sampai pada hari ia berangkat menuju ke tempat pengantin perempuan.

Pagi hari berikutnya maka orang tua pihak pengantin laki-laki mengundang orang banyak supaya ikut mengantar anak berangkat ke rumah pihak perempuan. Setelah semua orang kumpul dan menyantap makanan yang telah disediakan serta pengantin laki-laki sudah siap dengan pakaiannya, sebelum menjelang siang hari maka pengantin laki-laki sebelum keluar dari rumah ia berdiri sambil memegang ujung rotan dengan menggunakan tangan sebelah kanan dan didampingi oleh satu orang untuk memegang payung, satu orang membawakan rambat dan memegang sipet serta satu orang lagi membawakan tas pakaian pengantin laki-laki tersebut. Di dalam rambat yang dibawa tersebut dimasukkan pakaian untuk pengantin laki-laki sebagai pakaian ganti, isin baliung (beliung), salipi behas (sejenis ketupat yang berisi beras) dan tanteluh manuk (telur ayam kampung). Pengantin laki-laki berangkat menuju ke tempat pengantin perempuan di perjalanan diiringi dengan pukulan gong. Sampai di tempat pengantin perempuan, di depan rumah pengantin perempuan pihak pengantin laki-laki disambut dengan lawang sekepeng yaitu masing-masing dari kedua belah pihak pengantin sama-sama mengadakan seni pencak silat untuk membuka lawang sekepeng tersebut dengan diiringi tetabuhan gendang dan gong. Setelah lawang sekepeng terbuka maka pengantin laki-laki berjalan masuk menuju ke pintu rumah pengantin perempuan, dan setelah sampai di depan pintu rumah, pengantin laki-laki di papas oleh basir dari pihak pengantin perempuan yaitu bertujuan untuk mamapas/membuang sial, dahiang, dan segala jenis pali. Setelah itu pengantin laki-laki menginjak sebutir telur yang diletakan di atas batu asa. Setelah itu baru pengantin laki-laki masuk rumah yang disambut oleh calon mertuanya dan pengantin laki-laki beristirahat mengganti pakaiannya.

Orang tua pengantin perempuan menyiapkan satu ekor babi kecil untuk upacara manawur pali, dimana dalam upacara tersebut akan dibuatkan sebuah rumah kecil, ketupat empat belas buah, tambak dan hambaruan satu buah, tekang hambaruan basir yang menawur pali, lamiang satu pucuk dan satu buah baliung untuk digigit. Manawur pali ini dimaksudkan agar penguasa pali dimana sifat-sifat buruk dari pali (pantangan) jangan mengganggu upacara perkawinan serta jangan mengganggu kehidupan kedua mempelai dalam berumah tangga. 


\section{Haluang Hapelek}

Pada malam harinya, orang tua pengantin perempuan menyiapkan sangku yang diisi beras, Hampatung Tabalien Hampatung Pelek (ukiran patung dari kayu besi), uang logam/perak disusun keliling sangku, telur ayam kampung, lilies lamiang didirikan di atas beras, botol undus (minyak kelapa), tampung tawar, parapen (tempat menyimpan bara api) untuk garu manyan. Setelah itu amak pasar (tikar pasar), dipaparkan di tengah-tengah rumah, serta diberikan pembatas kain panjang untuk membatasi ruangan rumah, kemudian ayam dipotong satu ekor untuk sakin pelek (manyaki pangantin). Selanjutnya orang tua pengantin perempuan menyiapkan satu orang tua (basir) sebagai mantir mamelek (orang yang bisa mamelek), ditambah dengan tukang luang (yang membantu pelaksanaan mamelek) sebanyak tiga orang.

Mereka berempat ini menjadi mantir pelek dan luang telu inyaki awi ayah pengantin perempuan serta diikatkan tekang hambaruae (biasanya diikatkan uang dengan kain). Selanjutnya orang tua dari pihak pengantin laki-laki juga menyiapkan satu buah lamiang, telur ayam kampung, satu buah baliung, kain hitam akan tutup uwan, bahalai sinjang entang (kain panjang), benang lapik luang (kain panjang), salipin behas, pinggan pananan serta seluruh jalan hadat yang telah disepakati bersama, serta menyiapkan satu orang tua sebagai mantir manyambut, yang selanjutnya beliau inyaki malas dan diikatkan tekang hambaruae.

Setelah itu mantir mamelek dan mantir manyambut berdialog melalui perantara luang telu (luang tiga). Seteleh dialog tersebut mencapai suatu kesepakatan, maka ditambah lagi dua orang luang karundi. Setelah menambah luang karundi tersebut, maka dinding pembatas di buka, dari pihak pengantin perempuan mengeluarkan sangku pelek, dilanjutkan mantir pelek manyaki semua peralatan haluang hapelek. Setelah selesai acara manyaki peralatan mamelek, maka dilanjutkan dengan acara haluang hapelek yaitu pelaksanaan pemenuhan barang adat dari pihak pengantin laki-laki kepada pihak pengantin perempuan yang biasanya jalan hadat tersebut sama dengan palaku orang tua si pengantin perempuan yang biasanya berupa: 1. Palaku (biasanya berupa sebidang tanah), 2. Saput (biasanya diuangkan), 3. Pakaian Sinde Mendeng (pakaian satu stel), 4. Garantung Kuluk Pelek (gong), 5. Lamiang Turus Pelek (Lilis lamiang), 6. Bulau Singgah Pelek (cincin sepasang sebagai emas kawin), 7. Lapik Luang (kain bahalai), 8. Sinjang Entang (kain bahalai), 9. Tutup Uwan (kain hitam), 10. Pinggan Pananan (peralatan makan), 11. Rapin Tuak (minuman biasanya berupa tuak/baram), 12. Timbuk Tangga (uang logam), 13. Bulau Ngandung (biaya perkawinan), 14. 
Batu Kaja (perhiasan untuk calon menantu perempuan/disampaikan pada acara pakaja manantu).

Barang-barang inilah diserahkan oleh pihak pengantin laki-laki kepada pihak perempuan melalui para luang. Setelah itu mantir pelek mengikat lamiang kepada pangantin perempuan sekaligus nampung nawar serta nyaki memakai darah ayam sakin pelek. Begitu juga mantir manyambut mengikat lamiang kepada pengantin laki-laki serta nampung nawar dan nyaki malas setelah selesai maka selesailah upacara haluang hapelek.

\section{Manyaki Penganten}

Pagi harinya di rumah tempat berlangsungnya upacara perkawinan, pihak keluarga memotong babi atau hewan lainnya. Setelah selesai barulah hewan-hewan tersebut dipotong. Darahnya diambil untuk mamalas/manyaki pengantin. Selanjutnya hati babi diperiksa betulbetul apakah dalam keadaan baik atau ada tanda yang tidak baik. Makanan yang akan disajikan untuk orang banyak sudah masak, maka pihak keluarga pengantin memberikan atau mempersilahkan kepada mantir manyambut, mantir mamelek dan luang lime untuk makan terlebih dahulu. Setelah itu mereka melaksanakan tugas untuk mamalas/manyaki pengantin. Sebelumnya orang tua pengantin perempuan menyiapkan batang sawang (pohon andong), uei (rotan), ranying bunu (tombak), amak pasar (tikar), garantung (gong) tempat pengantin duduk, makanan sahur parapah/Putir Santang, darah ayam dan babi, air dalam mangkok, tanah dipinggir mangkok, tambak timbuk tangga, baliung, ringgit perak satu buah, jangkut, tasal, katip, jala, tutup ketel, panginan tingkes, sipa, air minum, parapen, garu manyan, undus (minyak kelapa), lilies manas dan air untuk cuci tangan.

Batang sawang, uei, ranying bunu didirikan di tengah-tengah amak pasar (tikar) yang sudah dibuka dan peralatan yang lain diletakkan di sekeliling batang sawang, garantung (gong) tempat pengantin duduk diletakkan pada arah matahari terbit. Setelah semua peralatannya sudah lengkap, maka pengantin berdua duduk di atas garantung (gong) sambil memegang batang sawang dan telunjuk pengantin berdua menunjuk ke atas. Setelah pengantin berdua duduk di atas garantung (gong), maka mantir mamelek dengan satu orang luang, manyaki semua peralatan yang sudah disiapkan dari yang kecil sampai yang besar. Setelah selesai manyaki peralatan hasaki hapalas, maka dilanjutkan dengan manyaki mamalas pengantin berdua, yang dilakukan oleh mantir mamelek dan satu orang luang. Setelah itu pengantin berdua makan makanan yang disebut panginan Putir Santang yang telah disiapkan. Dan kemudian mereka berdua dilanjutkan memakan sipa. Setelah selesai 
maka mereka berdua berdiri dan berjalan menuju ke pintu rumah dan bersama-sama menangkap tiang pintu rumah sambil manukiy (teriakan khas Dayak) sebanyak tujuh kali.

Selanjutnya para orang tua kedua belah pihak memberikan nasehat-nasehat dan petuah kepada pengantin berdua untuk bekal mengarungi rumah tangga. Dan kepada para tamu dan undangan dipersilahkan untuk menikmati makanan yang telah disiapkan dan memberikan ucapan selamat kepada mempelai berdua. Setelah semua rangkaian acara selesai, maka pengantin berdua menjalankan pali (pantangan) selama tujuh hari yaitu tidak boleh berjalan keluar rumah dan tidak boleh bertamu ke rumah orang lain. Setelah pali (pantangan) tersebut selesai maka pengantin berdua maruah pali (melepas pali) yaitu dengan cara berangkat menimba air, berangkat mencari ikan, berangkat mencari kayu, lawas. Setelah selesai maka dilanjutkan dengan pengantin berdua bertamu ke tempat beberapa keluarga dekat, maka selesailah seluruh rangkaian upacara perkawinan tersebut.

\section{Nilai-Nilai Pendidikan Hindu Dalam Upacara Perkawinan Umat Hindu Kaharingan Suku Dayak Ngaju}

Nilai-nilai pendidikan Hindu yang akan digali dalam upacara perkawinan umat Hindu Kaharingan suku Dayak Ngaju yaitu:

\section{Nilai Konstruktif}

Untuk mengkaji nilai-nilai konstruktif di dalam upacara perkawinan umat Hindu Kaharingan suku Dayak Ngaju dapat ditelaah berdasarkan nilai-nilai religius yang kaya akan simbol-simbol religi yang mengandung makna positif untuk ditransfer kepada generasi muda Hindu Kaharingan agar meyakini dan mengamalkan nilai-nilai suci tersebut di dalam kehidupannya bermasyarakat.

Nilai sama halnya dengan ilmu pengetahuan lain yang bersumber dan diperoleh dari data yang ada serta mengandung suatu kebenaran sesuai dengan sudut pandang dari mana dikaji masalah tersebut" (Musna, 1994: 2). Dimana nilai merupakan salah satu faktor utama dalam mewujudkan tata laksana dalam suatu pergaulan masyarakat maupun membina keluarga. Jadi nilai sangat penting artinya dalam suatu kehidupan, sebab nilai tersebut mampu memberikan arah tujuan dan petunjuk dalam menuangkan inspirasi kehidupan. Nilai konstruktif dalam upacara perkawinan umat Hindu Kaharingan sesuai dengan teori belajar konstruktivisme menyatakan bahwa pengetahuan dibangun dalam pikiran anak, dimana anak akan lebih banyak belajar dari pengalaman dan mampu berinteraksi dengan lingkungannya. Dimana dalam upacara perkawinan umat Hindu Kaharingan Dayak Ngaju kita dapat mengkontruksi nilai-nilai kebenaran yang terkandung di dalam upacara perkawinan tersebut 
dari berbagai simbol-simbol religius, dari doa-doa suci dan makna sarana upacara yang digunakan untuk dikenal, dihayati dan diamalkan oleh generasi muda Hindu Kaharingan kedepan.

\section{Nilai Ritual}

Apabila kita lihat dari proses awal sampai terakhir pelaksanaan upacara perkawinan maka jelaslah bahwa upacara perkawinan adalah sakral dan suci tidak dilakukan dengan main-main melainkan melalui proses yang panjang. Nilai-nilai kebenaran yang terkandung di dalam acara mananggar janji ini bahwa upacara perkawinan adalah sakral dan merupakan suatu komitmen bersama yang harus disepakati bersama, bukan upacara salah satu pihak saja melainkan upacara milik bersama kedua belah pihak. Apabila ada salah satu pihak yang tidak berkomitmen di dalam menempati janji yang tertuang dalam kontrak hisek maka keluarga tersebut akan mendapatkan nilai yang negatif dalam kehidupannya bermasyarakat dan dianggap tidak beradat. Dari proses awal sudah sangat jelas bahwa nilai pendidikan ritual perkawinan umat Hindu adalah sakral dan suci, bukan upacara main-main dan sekehendak hati, melainkan harus melalui proses komunikasi yang panjang dan penanaman komitmen bagi kedua belah pihak untuk mempertahankan keberlangsungan proses sampai kepada tahap pelaksanaan upacara perkawinan.

Nilai ritual di perkawinan Hindu Kaharingan Dayak Ngaju diharapkan kehidupan perkawinan dapat memberikan sinar terang seperti matahari, sehingga kehidupannya akan bersinar, bahagia dan sejahtera. Dalam upacara penganten mandai, pengantin laki-laki disambut dengan lawang sekepeng yang intinya adalah untuk membuka segala halangan dan rintangan yang nantinya akan menghalangi kehidupan dalam berumah tangga. Setelah sampai di depan pintu rumah, pengantin laki-laki di papas oleh basir dari pihak pengantin perempuan yaitu bertujuan untuk mamapas/membuang sial, dahiang, dan segala jenis pali. Setelah itu pengantin laki-laki menginjak sebutir telur yang diletakan di atas batu asa. Setelah itu baru pengantin laki-laki masuk rumah yang disambut oleh calon mertuanya dan pengantin laki-laki beristirahat mengganti pakaiannya. Dilanjutkan manawur pali ini dimaksudkan agar penguasa pali dimana sifat-sifat buruk dari pali (pantangan) jangan mengganggu upacara perkawinan serta jangan mengganggu kehidupan kedua mempelai dalam berumah tangga.

Nilai ritual dalam upacara haluang hapelek tergambar dalam pemenuhan jalan hadat dari pihak laki-laki kepada pihak perempuan. Pemenuhan jalan hadat ini sejalan dengan Firman Ranying Hatalla Langit dalam Kitab Suci Panaturan Pasal 30 Ayat 45: 
Iyoh Tingang Sinau Raja garing Hatungku, Narai Bulan Salae amun

Kalute Panalataie, Taluh ije manjadi kalabien Kambang Palakungku, iete

Banama Bulau Pahalendang Tanjung, Anjung Rabia Pahalingei Luwuk,

Tuntang Bukit Lampayung Nyahu

Artinya:

Iya Suamiku Raja Garing Hatungku, Baiklah Kalau Memang Demikian yang Kamu Kehendaki, Apa yang Ingin aku Mintakan lebih dari Mas Kawin itu yaitu Banama Bulau Pahalendang Tanjung, Anjung Rabia Pahalingei Luwuk dan Bukit Lampayung Nyahu.

Ada satu permintaan khusus dari Nyai Endas Bulau Lisan Tingang yaitu ia menginginkan sebuah peti mati dan nantinya memiliki anak keturunan yang gagah berani, pintar harati. Nilai dari kelebihan palaku tersebut bahwa perkawinan hanya dapat bahagia bila perkawinan tersebut hanya dipisahkan oleh kematian bukan oleh yang lain, ini terlihat dari simbol permintaan berupa peti mati (Pranata,dkk,2009;22).

Nilai ritual atau kebenaran dalam upacara perkawinan disaat pelaksanaan perkawinan keluarga mengorbankan hewan korban sebagai korban suci berupa ayam dan babi yang diambil darahnya untuk manyaki dan mamalas pengantin, hal ini melambangkan nilai ketulusan dan yadnya kepada Ranying Hatalla Langit agar memberkati perkawinan tersebut, sehingga perkawinan berjalan dengan lancar dan baik, serta kehidupan kedua pasangan di dalam kehidupan berumah tangga dapat selalu hidup rukun, damai, bahagia dan sejahtera. Setelah manyaki pengantin selesai, dimana kedua mempelai duduk di atas gong dan memegang pohon sawang sambil tangannya menunjuk ke atas, dan duduk menghadap ke arah matahari terbit. Hal ini memiliki nilai mohon doa restu kepada sang penguasa di atas, yaitu Ranying Hatalla Langit agar menyertai perkawinan, dan perkawinan tersebut diharapkan menghasilkan keluarga yang hidup seperti matahari mampu memberikan terang bagi seluruh kehidupan khususnya bagi kehidupan mereka berdua dan bagi seluruh keluarga.

\section{Nilai Positif}

Nilai-nilai positif atau nilai-nilai kebaikan dalam upacara perkawinan tercermin dari mantra-mantra yang diucapkan dalam doa suci pada saat upacara manyaki pengantin, seperti:

1. Nyakiku tutuk tunjuk sarapumpung panyurung nanjung, nyurung kea tuah rajaki ketun ndue belum palus mumpung panatau panuhan anak jarian.

2. Nyakiku likut tatap malapatap sial kawe tamanang tambisu.

3. Nyakiku buku laling hila luar, maling malewar peteh liau matei, nyakiku buku laling hila huang, bataling aseng nyaman ketua ndue belum.

4. Nyakiku tambang takep mangat nambang kayun penyang karuhei tatau, nambang tuah rajaki. 
5. Nyakiku utut mangat batuntut ketua ndue umba kare gawin uluh ije bujur kabajuran.

6. Nyakiku kukut hila sambil hapam ngakis mangian utang silih, lau hutus, kukut hila gantau hapam mukut tuah rajaki untung panjang.

7. Nyakiku sikum hapan nyiku hagagian peres baratus area manggian tamanang tambisu.

8. Nyakiku Rahepan hapam naharep kare raja awing beken dia tau giring bulum.

9. Nyakiku Likut hapam hatalikut umba sial kawe pali endus dahiang baya taluh je papa.

10. Nyakiku Balengkung tingang batengkung kambang tarung ketun belum tatau manyambung.

11. Nyakiku Batu Junjun kare purum mahunjun kea kambang tarung ketun belu.

12. Nyakiku hapan dahan bawui tuh mangat kasaingen aseng nyaman ketun ndue hayak batuah marajaki, te kea muwur kuh behas tuh mangat kilau behas ije tau mangkar manyiwuh nangalan ije supak ije gantang tau naratang pulu, kalute kea ampin tuah rajaki ketun ndue belum. Nantisan kuh minyak bangkang haselan tingang uring katilambung nyahu ije belum gantung-gantung indu tihang lewu pulu, mangat gantung kea sewut saritan ketun ndue belum mangun betang panjang huma hai palataran lumbah. te kea sanaman tuh mangat katekang mahambaruan ketun ndue aluh tampapulu nyahu batengkung dia tau giring bulu (Agan,2005;24).

Nilai positif dalam mantra manyaki pengantin oleh basir adalah bentuk permohonan kepada Ranying Hatalla Langit adalah agar kehidupan mereka berdua di dalam kehidupan berumah tangga memperoleh keturunan yang baik, menghilangkan segala sial dan berumur panjang, memiliki harta kekayaan berlimpah, dapat mengikuti segala pekerjaan orang yang baik, supaya tidak tertimpa musibah, dapat menghadapi tantangan, tidak takut menghadapi orang lain atau persaingan dalam kehidupan, menghilangkan pantangan hidup, serta mampu menjadi pedoman bagi orang lain. Nilai-nilai positif atau nilai-nilai kebaikan inilah yang akan ditransfer kepada generasi muda Hindu Kaharingan sehingga nantinya upacara perkawinan yang sakral dan suci tersebut tidak akan hilang atau punah oleh perkembangan zaman. Dimana juga diharapkan generasi muda mampu melaksanakan dan menghayati nilai-nilai positif tersebut.

\section{Nilai Kognitif}

Nilai kognitif dalam upacara perkawinan umat Hindu Kaharingan Dayak Ngaju yakni berupa nilai pengetahuan atau mentransformasi nilai-nilai yang ada di dalam upacara perkawinan tersebut, seperti yang tertuang dalam Kitab Suci Panaturan pasal 41 Bawi Ayah Hadurut Bara Lewu Telu, nanturung Pantai Danum Kalunen ayat 2 mengungkapkan:

Amun Kalute ampie kakare taluh handiai, huang pambelum anak esun Raja Bunu Mijen Pantai Danum Kalunen, ije jadi uras Nalingau kakare ajar RANYING HATALLA LANGIT, Ie RANYING HATALLA Hamauh Hayak Nyahuan Raja Uju Hakanduang Kanaruhan Hanya Basakati, uka hadurut Nanturung Lewu Telu Kalabuan Tingang, Rundung Epat Kalehulun Talawang.

Artinya: 
Memperhatikan keadaan kehidupan anak cucu Raja Bunu yang hidup di Pantai Danum Kalunen yang sudah banyak melupakan ajaran RANYING HATALLA, maka oleh sebab itu RANYING HATALLA berfirman dan memerintahkan Raja Uju Hakanduang Kanaruhan Hanya Basakati supaya segera turun ke Lewu Telu Kalabuan Tingang, Rundung Epat Kalehulun Talawang.

Berdasarkan dari ayat ini maka tercermin nilai-nilai kognitif yang terjadi pada saat anak keturunan Raja Bunu (umat manusia) sudah lupa akan ajaran yang telah diberikan contoh oleh Ranying Hatalla, maka Ranying Hatalla segera mengirim Raja Uju Hakanduang untuk mengingatkan dan mengajarkan kembali ajaran Ranying Hatalla kepada umat manusia, sehingga anak manusia kembali ingat dan tetap menjalankan ajaran-ajaran yang telah difirmankan. Upacara perkawinan yang sakral dan suci dan melibatkan orang banyak tidak mengenal tua ataupun muda, merupakan proses transformasi nilai dalam upacara perkawinan dimana anak-anak atau para remaja juga terlibat dalam mensukseskan upacara perkawinan tersebut, dimana para orang tua biasanya membawa anak-anak mereka untuk melihat proses pelaksanaan upacara dari awal sampai akhir. Pada saat pelaksanaan upacara manyaki pengantin dimana para basir mengoleskan darah ayam/darah babi kepada kedua mempelai, biasanya suasananya hening dan hikmat, semuanya dengan penuh rasa ingin tahu akan doadoa yang disampaikan oleh basir kepada kedua mempelai, semua orang menghayati apa isi mantra yang disampaikan hal ini adalah bentuk proses pentransferan ilmu berupa mantramantra suci yang sangat jarang didengar maupun dibaca oleh generasi muda. Dengan mereka melihat langsung dan terlibat dalam upacara tersebut maka mereka dapat belajar dan mempelajari apa saja makna-makna dalam yang terkandung dalam upacara perkawinan tersebut, apa saja sarana dan prasarana yang digunakan, lalu bagaimana proses pelaksanaannya. Semuanya akan terlihat jelas jika memang diperhatikan secara sungguhsungguh.

Dari proses hakumbang auh, maja misek, mananggar janji sampai kepada penganten mandai, haluang hapelek, manyaki pengantin dan sampai kepada meruah pali diharapkan agar terjadi perubahan paradigma berpikir generasi muda Hindu Kaharingan terhadap pelaksanaan upacara perkawinan tersebut dari yang dianggap biasa-biasa saja menjadi suatu yang bernilai suci dan sakral. Pandangan generasi muda yang menganggap upacara keagamaan adalah biasa-biasa saja dan jarang memperhatikan dengan sungguh-sungguh, diharapkan berubah menjadi taat dan yakin kepada upacara perkawinan tersebut, hal ini dapat dilakukan dengan membawa mereka terlibat langsung, melihat secara jelas dan memperhatikan secara sungguh-sungguh proses pelaksanaan perkawinan tersebut maka akan 
berdampak kepada perubahan paradigma berpikir mereka apabila mereka benar-benar meyakini akan upacara tersebut.

\section{Nilai Expresif}

Nilai expresif dalam upacara perkawinan umat Hindu Kaharingan Dayak Ngaju adalah mengungkapkan tentang nilai-nilai keindahan, nilai-nilai rasa bakti yang tertuang dalam upacara perkawinan baik dari sarana upacaranya sampai kepada proses pelaksanaan upacaranya. Nilai-nilai keindahan dalam upacara perkawinan tercermin dari sarana dan prasarana yang digunakan seperti Sangku Tambak Raja yaitu bahan dari kuningan yang diukir indah dengan berbagai ukiran khas, yang mana diisikan beras dan bunga-bungaan serta hiasan dari daun kelapa. Hal ini apabila dilihat memiliki nilai keindahan yang sangat tinggi, karena tidak semua orang bisa membuat atau menghias dari sangku tersebut. Pada saat acara penganten mandai, pengantin membawa tas yang terbuat dari rotan (rambat) hal ini juga mensimbolkan suatu keindahan seni anyam-anyaman, karena hanya segelintir orang saja yang mampu menganyam rotan menjadi sebuah tas yang disebut dengan rambat, nilai seni atau keindahan juga terlihat dari ukiran rotan yang dibawa oleh pengantin laki-laki pada saat penganten mandai, dimana ujung rotan diukir menyerupai manusia, hal ini juga melambangkan nilai seni ukir yang tinggi dan mengandung unsur keindahan, bunyi tetabuhan gendang dan gong yang memiliki irama yang khas pada saat acara membuka lawang sekepeng juga mencerminkan seni irama yang tinggi dan sangat indah, alunan gong dan gendang mengiringi gerakan pencak silat khas Kalimantan Tengah, melambangkan seni gerak dan seni musik yang indah dan tidak semua orang bisa melakukannya. Pada saat upacara manyaki pengantin, kedua mempelai laki-laki dan perempuan didandani dengan pakaian adat khas Kalimantan Tengah yang sangat meriah dan terkesan indah juga melambangkan nilai keindahan yang sangat tinggi. Jadi di dalam pelaksanaan upacara perkawinan umat Hindu Kaharingan Dayak Ngaju kita dapat melihat berbagai seni yang melambangkan nilai-nilai keindahan baik seni gerak, seni musik, seni ukir, seni hias pengantin dan seni anyaman.

Dalam upacara perkawinan umat Hindu Kaharingan juga mengandung nilai bakti, nilai bakti disini terlihat dari pelaksanaan awal perkawinan sampai kepada acara terakhir upacara perkawinan dimana para proses awal upacara perkawinan orang tua pengantin lakilaki mengundang seluruh pihak keluarga untuk hadir ke rumahnya mengantar anaknya ke rumah pihak perempuan dengan mengorbankan hewan korban berupa ayam, disaat 
penyembelihan hewan korban, sebelum disembelih dibacakan mantra-mantra suci bahwa hewan korban tersebut bukan mati sia-sia melainkan sebagai korban suci untuk Ranying Hatalla Langit dan Sahur Parapah yang selalu menjaga keluarga mereka agar mereka di dalam berangkat mengantar anaknya ke rumah pengantin perempuan selamat sampai tujuan dan berjalan dengan baik. Rasa bakti juga tercermin dengan berkumpulnya orang banyak di dalam pelaksanaan upacara perkawinan. Dengan berkumpulnya orang banyak dari seluruh keluarga untuk hadir juga melambangkan nilai bakti kepada sesama, dimana pihak pelaksana perkawinan menyuguhkan hidangan dengan tulus ikhlas kepada semua orang yang hadir tanpa memandang status seseorang. Nilai bakti ini juga sebagai bentuk bakti anak kepada orang tuanya sebagai bakti untuk meneruskan keturunan sebagai kelanjutan dari silsilah keluarga. Dimana hanya melalui proses perkawinan inilah akan terjadi proses penerusan keturunan keluarga. Dimana diharapkan dengan melalui perkawinan tersebut akan lahir anakanak yang berbudi pekerti luhur, yang berbakti pandai dan gagah perkasa. Hal tersebut dapat dianalisa dari konsep ajaran Hindu Kaharingan yaitu "Huma Hai Betang Panjang Palantaran Lumbah" dengan kriteria menurut sastra lisan yang terkenal pada suku Dayak Ngaju, yakni Sasana Bandar. Dalam kehidupan perkawinan antara Tamanggung Ratu Tinggi dan Nyai Ratu Bawi di Kerajaan Luwuk Dalam Batawi, terjadi dialog, bahwa putra/putri yang bagaimana yang mampu melanjutkan kepemimpinan kerajaan, terjadi dialog serius antara keduanya dan berkesimpulan bahwa anak keturunan yang dikehendaki adalah mampu menjadi pemimpin dengan kriteria sebagai berikut.

1. Putra/Putri je pintar harati di tapa tangkiri, pintar andal dia tara timbal (cerdik, pandai, cendikia)

2. Bakena jatun suntu manumun, namunan anak Hatalla hadurut, bahalap jatun tanding tampengae, numunan Bulau Bawin Jatha Lampang (penampilan baik dan berwibawa)

3. Tanju tanjung mamutus basara halus, mende-mendeng manggetu hinting bunu panjang (Bahadat, pandai dan adil memutus segala perkara)

4. Genep bulan toko pasar bajajar, genep matan andau balawa, nikap bulau pungkal raja (mampu memakmurkan masyarakatnya)

5. Habayang pulang mandau apang dia tau kalah, hasampuk Talawang dia tau marup (pantang marah selalu memenangkan pertempuran/peperangan) (MB-AHK,1977:45)

Dengan kriteria tersebut, maka seorang anak nantinya akan dihormati dan disegani oleh masyarakatnya. Nilai bakti juga tercermin dari penyerahan palaku dari pihak laki-laki kepada pihak perempuan dimana salah satu barang palaku tersebut adalah sinjang entang yaitu berupa kain panjang yang diserahkan kepada orang tua si perempuan, sebagai ganti kain panjang pada saat orang tua melahirkan anaknya dulu. Ini menandakan nilai bakti kepada 
orang tua sebagai balas budi dari anak untuk orang tuanya. Begitu juga penyerahan palaku berupa tutup uan yaitu berupa kain hitam, maknanya adalah kain hitam tersebut diserahkan untuk nenek pengantin perempuan, sebagai tutup uban si nenek. Jadi nilai bakti disini, selain bakti kepada antar sesama, bakti kepada orang tua, juga melambangkan bakti kepada Ranying Hatalla Langit dan juga bakti kepada para leluhur.

\section{Simpulan}

Upacara perkawinan menurut ajaran agama Hindu Kaharingan Dayak Ngaju terdapat berbagai rangkaian upacara yang harus dilaksanakan oleh kedua mempelai yaitu pasca upacara perkawinan yang meliputi: 1). Hakumbang Auh.2). Maja Misek (Mamanggul). 3). Mananggar Janji, dilanjutkan dengan pelaksanaan upacara perkawinan dengan beberapa rangkaian acara yaitu: 1) Panganten Mandai. 2). Haluang Hapelek. 3). Manyaki Panganten. Nilai-nilai pendidikan yang terkandung dalam upacara perkawinan umat Hindu Kaharingan meliputi: A) Nilai Pendidikan Konstruktif, nilai pendidikan konstruktif dalam upacara perkawinan umat Hindu Kaharingan Dayak Ngaju adalah sakral dan suci, bukan upacara main-main dan sekehendak hati, melainkan harus melalui proses komunikasi yang panjang dan penanaman komitmen bagi kedua belah pihak untuk mempertahankan keberlangsungan proses sampai kepada tahap pelaksanaan upacara perkawinan selesai. Nilai ritual atau kebenaran dalam upacara perkawinan disaat pelaksanaan perkawinan keluarga mengorbankan hewan korban sebagai korban suci hal ini melambangkan nilai ketulusan dan yadnya kepada Ranying Hatalla Langit agar memberkati perkawinan tersebut, sehingga perkawinan berjalan dengan lancar dan baik, serta kehidupan kedua pasangan di dalam kehidupan berumah tangga dapat selalu hidup rukun, damai, bahagia dan sejahtera. Kepada sang penguasa di atas, yaitu Ranying Hatalla Langit agar menyertai perkawinan, dan perkawinan tersebut diharapkan menghasilkan keluarga yang hidup seperti matahari mampu memberikan terang bagi seluruh kehidupan khususnya bagi kehidupan mereka berdua dan bagi seluruh keluarga. B). Nilai Pendidikan Positif dalam upacara perkawinan umat Hindu Kaharingan Dayak Ngaju yaitu berupa nilai-nilai positif atau nilai-nilai kebaikan yang ada tercermin di dalam pelaksanaan upacara perkawinan. Nilai-nilai positif tersebut tercermin dari simbol-simbol dari mantramantra suci yang dilantunkan oleh basir sebagai pelaksana upacara. Sangatlah jelas bahwa semua orang yakin dan percaya bahwa lantunan mantra-mantra sambil mengoleskan darah hewan korban kepada kedua mempelai oleh basir adalah bentuk permohonan kepada Ranying Hatalla Langit untuk menyertai kedua mempelai. Nilai-nilai positif atau nilai-nilai kebaikan 
inilah yang akan ditransfer kepada generasi muda Hindu Kaharingan sehingga nantinya upacara perkawinan yang sakral dan suci tersebut tidak akan hilang atau punah oleh perkembangan zaman. Dimana juga diharapkan generasi muda mampu melaksanakan dan menghayati nilai-nilai positif tersebut. C) Nilai Pendidikan Kognitif, dalam upacara perkawinan umat Hindu Kaharingan Dayak Ngaju yakni berupa nilai pengetahuan atau mentransformasi nilai-nilai yang ada di dalam upacara perkawinan tersebut, baik itu nilai ritual, nilai positif/nilai kebaikan maupun nilai-nilai lainnya. Dengan melalui serangkaian pelaksanaan upacara perkawinan tersebut baik dari proses hakumbang auh, maja misek, mananggar janji sampai kepada penganten mandai, haluang hapelek, manyaki pengantin dan sampai kepada meruah pali diharapkan agar terjadi perubahan paradigma berpikir generasi muda Hindu Kaharingan terhadap pelaksanaan upacara perkawinan tersebut dari yang dianggap biasa-biasa saja menjadi suatu yang bernilai suci dan sakral. Pandangan generasi muda yang menganggap upacara keagamaan adalah biasa-biasa saja dan jarang memperhatikan dengan sungguh-sungguh, diharapkan berubah menjadi taat dan yakin kepada upacara perkawinan tersebut, hal ini dapat dilakukan dengan membawa mereka terlibat langsung, melihat secara jelas dan memperhatikan secara sungguh-sungguh proses pelaksanaan perkawinan tersebut maka akan berdampak kepada perubahan paradigma berpikir mereka apabila mereka benar-benar meyakini akan upacara tersebut. D) Nilai Pendidikan Expresif upacara perkawinan umat Hindu Kaharingan mengungkapkan tentang nilai-nilai keindahan, nilai-nilai rasa bakti yang tertuang dalam upacara perkawinan baik dari sarana upacaranya sampai kepada proses pelaksanaan upacaranya. Di dalam pelaksanaan upacara perkawinan umat Hindu Kaharingan kita dapat melihat berbagai seni yang melambangkan nilai-nilai keindahan baik seni gerak, seni musik, seni ukir, seni hias pengantin dan seni anyaman. Nilai bakti juga tercermin dari penyerahan palaku dari pihak laki-laki kepada pihak perempuan dimana salah satu barang palaku tersebut adalah sinjang entang yaitu berupa kain panjang yang nantinya barang tersebut diserahkan kepada orang tua si perempuan, sebagai ganti kain panjang pada saat orang tua melahirkan anaknya dulu. Ini menandakan nilai bakti kepada orang tua sebagai balas budi dari anak untuk orang tuanya. Begitu juga penyerahan barang palaku berupa tutup uan yaitu berupa kain hitam, maknanya adalah kain hitam tersebut diserahkan untuk nenek pengantin perempuan, sebagai tutup uban si nenek. Jadi nilai bakti disini, selain bakti kepada antar sesama, bakti kepada orang tua, juga melambangkan bakti kepada Ranying Hatalla Langit dan juga bakti kepada para leluhur. 


\section{Daftar Pustaka}

Agan, Thian (2005) Buku Upacara Perkawinan Umat Agama Hindu Kaharingan. Kanwil Depag Provinsi Kalimantan Tengah.

Hadikusuma, Hilman. (1977). Hukum Perkawinan Adat. Bandung: Alumni. (1993) Antropogi Agama Bagian I, Bandung: Citra Aditya Bakti

MB-AHK (1977) Kaharingan Beserta Aspek-Aspeknya. Palangka Raya

Musna, I Wayan (1994) Kamus Agama Hindu, Denpasar : Upada sastra.

Pranata (2009) Upacara Ritual Perkawinan Umat Hindu Kaharingan (Dalam Kitab Suci Panaturan) Filosofis Perkawinan Nyai Endas Bulau Lisan Tingang Dan Raja Garing Hatungku,. Surabaya : Paramitha,

Pudja, I Gede (1978) Manawa Dharma Sastra, Weda Smerti, Jakarta: Departemen Agama RI. Tim Penyusun (2001) Panaturan, Palangka Raya, Majelis Besar Agama Hindu Kaharingan (MB-AHK) Pusat Palangka Raya 